\title{
Stereocontrolled Crotylation of 4-Acetoxy-2-azetidinone for the Synthesis of 1 $\beta$-Methylcarbapenem Precursor
}

\author{
Hye Jung Kim, Sung Ryoung Lee, Seok Won Kang, and Sung Hoon Kim* \\ Department of Chemistry, Konkuk University, Seoul 143-701, Korea. ${ }^{*}$ E-mail: shkim@konkuk.ac.kr \\ Received June 1, 2010, Accepted July 15, 2010
}

Key Words: 4-Acetoxy-2-azetidinones, Stereoselective crotylation, $1 \beta$-Methylcarbapenem

The $1 \beta$-methylcarbapenems are one of the important $\beta$-lactam antibiotics and become the object of ongoing pharmaceutical development. ${ }^{1}$ For example, meropenem ${ }^{2}$ and ertapenem ${ }^{3}$ have excellent spectrum of antibiotic activities and good resistance to renal dehydropeptidase I (DHP-I). ${ }^{4}$
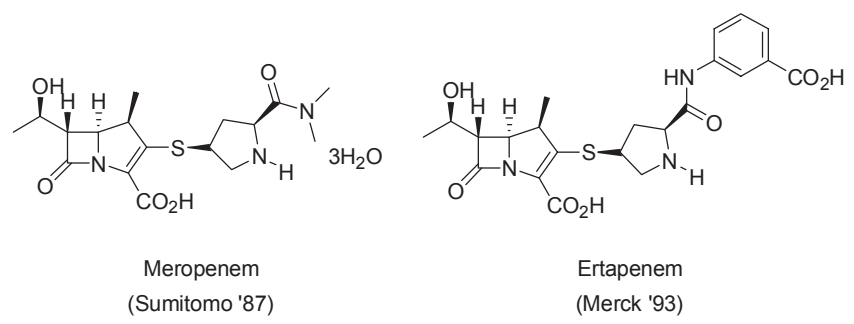

One of the main problems for the synthesis of $1 \beta$-methylcarbapenems from commercially available starting material such as $(3 R, 4 R)-4-($ acetyloxy)-3-[(1R)-1-[[(1,1-dimethylethyl) dimethylsilyl] oxy] ethyl]-2-azetidinone $\mathbf{1}$ is the introduction of carbon substituent at the C-4 position of the azetidinone moiety. ${ }^{5}$ Although a number of Reformatsky type enolate additions to azetidinones have been described, ${ }^{6}$ only a few examples regarding crotylation of azetidinone were reported with low or moderate yields, poor stereoselectivity or non-practical applicability.
1

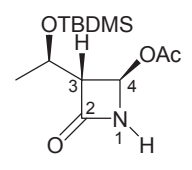

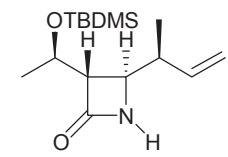

2

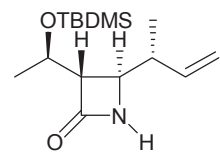

3<smiles>CC(C=O)C1NC(=O)C1(C)C(C)[R16](C)(C)C</smiles>

4

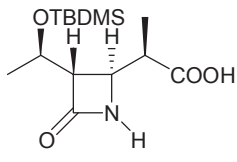

5
Several crotylation methods involving crotyl bromide with zinc powder ${ }^{7 \mathrm{a}, 7 \mathrm{~b}}$ and indium powder ${ }^{7 \mathrm{c}}$ are reported to give 2 and 3 as a 1:1 mixture of diastereomers. These methods are simple and practical, however, they are not stereoselective. Other methods using organometallic tri- $n$-butyl crotylstannane ${ }^{7 \mathrm{~d}, 7 \mathrm{e}}$ and (Z)-2-butenylchlorodimethylsilane ${ }^{7 \mathrm{f}}$ have been reported. Although the use of tri- $n$-butylcrotylstannane gives a $\operatorname{good} \beta$ to $\alpha$ ratio $(5: 1)$ of diastereomers with the desired 2 as major component, the yield of $\mathbf{2}$ from $\mathbf{1}$ is low (35\%). Also the use of stannyl and silyl derivatives are non-practical in industrial process. These are the reasons why a facile and efficient method for the stereoselective crotylation at $\mathrm{C} 4$ position should be developed. In the actual industrial process of carbapenems, compound $\mathbf{2}$ is converted directly into aldehyde $4^{8}$ or carboxylic acid $5^{9}$ followed by further functionalization.

We report herein an extremely simple and stereoselective, and therefore industrially feasible synthesis of $\mathbf{2}$ from the commercially available acetoxyazetidinone $\mathbf{1}$. In order to find the optimum conditions for stereocontrolled syntheses of $\mathbf{2}$, acetoxyazetidinone $\mathbf{I}$ was reacted with crotyl bromide and metals in the presence of ligands and Lewis acids. The control experiments with various metals in the absence of chiral ligands exhibited no stereoselectivity in all cases. The amount of tested ligands and Lewis acids varies from 0.0125 to 1.0 mole equivalents. The kinds of tested Lewis acids are $\mathrm{AgCl}, \mathrm{PdCl}_{2}, \mathrm{AgOTf}$, $\mathrm{CuCl}, \mathrm{CuCN}, \mathrm{Cu}(\mathrm{OAc})_{2}, \mathrm{InCl}_{3}, \mathrm{PbBr}_{2}, \mathrm{GaCl}_{3}, \mathrm{Ti}(\mathrm{OPr})_{4}, \mathrm{CeCl}_{3}$, $\mathrm{Sc}(\mathrm{OTf})_{3}, \mathrm{ZnCl}_{2}$ and $\mathrm{ZnBr}_{2}$, The kinds of tested chiral ligands are cinchonine, cinchonidin, quinine, quinidine, norephedrin, $(R)$-(+)-BINAP, $(S)-(-)$-BINAP, $(S)$-(-)-amino-3-phenyl-1-propanol, $(R)-(-)-2-$ phenylglycinol, amino-2-indanol, $(S)-(+)-$ amino-1-butanol, $O$-acetylcinchonine, $O$-acetylcinchonidine, $(R)$-BINOL, $(S)$-BINOL, $(S)$-2-aminopropanol, $(R)$-2-aminopropanol, $O$-acetylquinine and $O$-acetylquinidine. The kinds of tested metals are zinc, aluminum, gallium and indium. Common solvents such as diethyl ether, dioxane, THF, DMF, DME and IPE are tested. After numerous trials, excellent results are obtained with zinc as a metal, $\mathrm{InCl}_{3}$ as a Lewis acid, and cinchonine as a ligand in diethyl ether. When the reaction was performed with catalytic amount of $\mathrm{InCl}_{3}$ (0.025 equiv), $\mathrm{Zn}$ (2.0 equiv) and cinchonine alkaloids ( 0.025 equiv) in diethyl ether at 25 $30{ }^{\circ} \mathrm{C}$, best results were obtained with reasonably good $\beta$ to $\alpha$ ratio $(5.0: 1.0)$ in $98 \%$ isolated yield. All ratios were observed from the ${ }^{1} \mathrm{H}-\mathrm{NMR}$ after work-up. The selected results of this approach are summarized in Table 1.

Interestingly, it is found that the $\beta$ to $\alpha$ ratios are reversed by simply using indium instead of zinc under same conditions (entry $9 \sim 12)$. The typical procedure is as follows. To a mixture of $\mathbf{1}$ ( $2.874 \mathrm{~g}, 10.0 \mathrm{mmol})$, cinchonidine $\left(0.074 \mathrm{~g}, 0.025\right.$ equiv), $\mathrm{InCl}_{3}$ $(0.044 \mathrm{~g}, 0.025$ equiv) in ether $(240 \mathrm{~mL})$ was added crotyl bromide (2.0 mL, 2.0 equiv) at $25 \sim 30{ }^{\circ} \mathrm{C}$ and the mixture was stirred for $30 \mathrm{~min}$. Zinc ( $0.654 \mathrm{~g}, 2.0$ equiv) granule purchased from Aldrich without further activation was added therein and 
Table 1. Barbier-type crotylation of 4-acetoxy-2-azetidinone

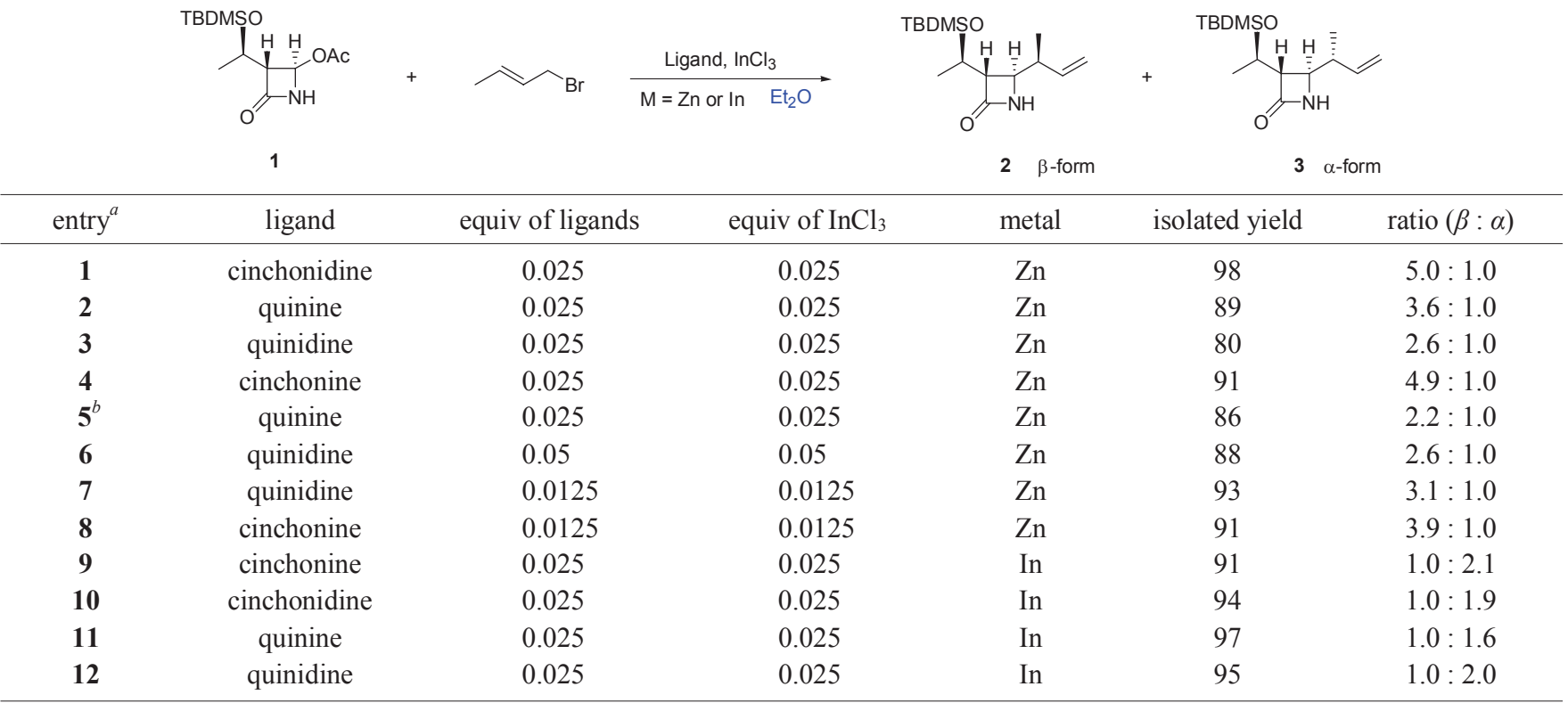

${ }^{a}$ The reactions were run with zinc or indium (2.0 equiv) and crotyl bromide (2.0 equiv) in $\mathrm{Et}_{2} \mathrm{O}$ at $25 \sim 30{ }^{\circ} \mathrm{C} .{ }^{b}$ The reaction was run at $0 \sim 5{ }^{\circ} \mathrm{C}$.

stirred for $2 \mathrm{~h}$. The reaction mixture was poured into saturated ammonium chloride solution $(40 \mathrm{~mL})$, extracted with ether (30 $\mathrm{mL} \times 2$ ). The organic layer was dried over anhydrous $\mathrm{Na}_{2} \mathrm{SO}_{4}$, evaporated in vacuo and chromatographed on a silica gel column to give white solid of 2 and 3 (2.780 g, 98\%). The product ratio was determined to be $5.0: 1.0$ by $400 \mathrm{MHz}{ }^{1} \mathrm{H}-\mathrm{NMR}$ analysis. ${ }^{7 b}$ Chromatographic separation of $\beta$-isomer from $\alpha$ isomer was not effective at this stage. The separation of the mixture of $\alpha, \beta$-isomers was well documented in the literature after desilylation followed by chromatography. ${ }^{7 \mathrm{~b}}$

To our knowledge, this is the best stereoselective synthesis of (4R)-4[(1S)-1-methylallyl]-2-azetidinone $\mathbf{2}$ with high yields. Some parts of these results are applied for the patent. ${ }^{10} \mathrm{We}$ anticipate that this methodology will be useful in the industrial process for the synthesis of $1 \beta$-methylcarbapenems from commercially available azetidinone $\mathbf{1}$.

Acknowledgments. This work was financially supported by Konkuk university 2009.

\section{References}

1. (a) Schmitt, S. M.; Salzmann, T. N.; Shih, D. H.; Christensen, B. G. J. Antibiot. 1988, 41, 780. (b) Deziel, R.; Favreau, D. Tetrahedron Lett. 1989, 30, 1345. (c) Guthikonda, R. N.; Cama, L. D.; Quesada, M.; Woods, M. F.; Salzmann, T. N.; Christensen, B. G. J. Med. Chem. 1987, 30, 871.

2. (a) Wells, J. S.; Trejo, W. H.; Principe, P. A.; Bush, K.; Geoegopapadakou, N.; Boner, D. P.; Sykes, R. B. J. Antibiot. 1982, 35, 184. (b) Leanza, W. J.; Wildonger, K. J.; Miller, T. W.; Christensen, B. G. J. Med. Chem. 1979, 22, 1435.

3. Yutaka, N.; Tadafumi, K.; Tetsuya, Y.; Takahiro, K. Org. Process
Res. Dev. 2003, 7, 649.

4. Kropp, H.; Sundelof, J. G.; Hajdu, R.; Kahan, F. M. Antimicrob. Agents Chemother. 1982, 22, 62.

5. (a) Kobayashi, T.; Ishida, N.; Hiraoka, T. J. Chem. Soc. Chem. Comm. 1980, 736. (b) Oida, S.; Yoshida, A.; Ohki, E. Chem. Pharm. Bull. 1980, 28, 3494. (c) Barrett, A. G. M.; Quayle, P. J. Chem. Soc. Chem. Comm. 1981, 1076. (d) Hirai, K.; Iwano, Y.; Fujimoto, K. Tetrahedron Lett. 1982, 23, 4025. (e) Deziel, R.; Favreau, D. Tetrahedron Lett. 1986, 27, 5687. (f) Kim, C. D.; Luh, B.; Partyka, R. A. Tetrahedron Lett. 1987, 28, 507. (g) Mori, M.; Oida, S. Bioorg. Med. Chem. Lett. 1993, 3, 2389. (h) Kondo, K.; Seki, M.; Kuroda, T.; Tamanaka, T.; Iwasaki, T. J. Org. Chem. 1997, 62, 2884.

6. (a) Kondo, K.; Seki, M.; Kuroda, T.; Yamanaka, T.; Iwasaki, T. J. Org. Chem. 1995, 60, 1096. (b) Ito, Y.; Sasaki, A.; Tamoto, K.; Sunagawa, M.; Terashima, S. Tetrahedron 1991, 47, 2801. (c) Shirai, F. J.; Nakai, T. J. Org. Chem. 1987, 52, 5491. (d) Fuenes, L. M.; Shinkai, I.; Salzmann, T. N. J. Am. Chem. Soc. 1986, 108, 4675. (e) Shibata, T.; Sugimura, Y. J. Antibiot. 1989, 42, 374. (f) Shibata, T.; Iino, K.; Tanaka, T.; Hashimoto, T.; Kameyama, Y.; Sugimura, Y. Tetrahedron Lett. 1985, 26, 4739.

7. (a) Uyeo, S.; Itani, H. Tetrahedron Lett. 1991, 32, 2143. (b) Imuta, M.; Itani, H.; Ona, H.; Hamada, Y.; Uyeo, S.; Yoshida, T. Chem. Pharm. Bull. 1991, 39(3), 663. (c) Kang, S.-K.; Baik, T.-G.; Jiao, X.-H.; Lee, K.-J.; Lee, C. H. Synlett 1999, 447. (d) Fliri, H.; Mak, C. P.J. Org. Chem. 1985, 50, 3438. (e) Katsumi, F.; Yuji, I.; Koichi, H. Tetrahedron Lett. 1985, 26, 89. (f) Haruta, J.; Nishi, K.; Kikuchi, K.; Matsuda, S.; Tamura, Y.; Kita, Y. Chem. Pharm. Bull. 1989, 37, 2338.

8. Hiroshi, O.; Hiroyuki, I.; Hiroaki, O. Jpn. Kokai Tokkyo Koho 1994, JP 06340618 A 19941213.

9. (a) Keita, N.; Teruyoshi, K; Masafumi, F.; Yasuyoshi, U. PCT Int. Appl. 2007, WO 2007145260 Application: WO 2007-JP61937 20070613. (b) Hikaru, I.; Shoichiro, U. Synlett 1995, 2, 213.

10. Kim, S. H.; Kang, S. W.; Ahn, H. J.; Kim, H. R.; Kim, Y. H. Repub. Korean Kongkae Taeho Kongbo 2009, KR 2009101581 A 20090929. 